\title{
Students' Opinions about Their Ninth Grade Biology Textbook: From the Perspective of Constructivist Learning Approach
}

\author{
Atilla Çimer $^{1} \&$ Sibel Coşkun ${ }^{2}$ \\ ${ }^{1}$ Fatih Faculty of Education, Karadeniz Technical University, Trabzon, Turkey \\ ${ }^{2}$ Institute of Educational Sciences, Karadeniz Technical University, Trabzon, Turkey \\ Correspondence: Atilla Çimer, Karadeniz Teknik Üniversitesi, Fatih Eğitim Fakültesi, Matematik ve Fen \\ Bilimleri Eğitimi Bölümü, Biyoloji Eğitimi Anabilim Dalı, D Blok, 2. Kat, No:207, Söğütlü, Akçaabat, Trabzon, \\ Turkey.
}

Received: April 20, 2018

Accepted: May 10, 2018

Online Published: May 15, 2018

doi:10.5539/jel.v7n4p201

URL: https://doi.org/10.5539/jel.v7n4p201

\begin{abstract}
The study aimed to determine students' opinions about their ninth grade biology textbook that had been created in accordance with the constructivist learning approach. On the basis of a detailed literature review of studies on textbooks; questionnaires used for assessment of textbooks; and constructivist learning approach, a questionnaire was created and administered to 751 students from 9 schools located in the city of Trabzon. The questionnaire was classified into the following sections: contents, learning-teaching activities, assessment and evaluation activities, and physical design. The Cronbach's alpha reliability coefficient was 0.94 , and the data were analyzed using SPSS 15.0. Multiple findings pertaining to each section were obtained. Overall, it was found that the students were satisfied with their ninth grade biology textbook. While the existence of various visuals was being appreciated by most of the students, some aspects of the textbooks should be developed in order better to support constructivist learning in classrooms. The study also revealed that the questionnaire developed might be used to evaluate textbooks in terms of their appropriateness to constructivist learning theory. The findings of the study are expected to contribute to improving design for future textbooks.
\end{abstract}

Keywords: textbook, student views, biology, constructivist learning approach

\section{Introduction}

Researchers generally agree that as the major conveyors of curricula, textbooks play a dominant role in modern education across different school subjects (K1lı̨ \& Seven, 2008; Pop-Păcurar \& Ciascai, 2010; Fan, Zhu \& Miao, 2013; Kashi, Andreeva \& Naeimi, 2015). Textbooks are designed with the aim of translating the abstractions of curriculum policy into operations that teachers and students can execute (Valverde, Bianchi, Wolfe, Schmidt, \& Houang, 2002; Kilıç, 2013; Mohammadia \& Abdib, 2014). In other words, textbooks are intended to mediate the intentions of curriculum policy designers and classroom instructors (Robinson, Fischer, Wiley \& Hilton, 2014; Kashi et al., 2015). Swanepoel (2010) reports that textbooks are the most frequently used learning support material, and the availability of high-quality textbooks is a critical factor for the successful implementation of educational reform. Teachers generally use textbooks as curriculum guides and sources for preparing lessons and the quality of textbooks have a great impact on the quality of their instruction (Ogan-Bekiroglu, 2007; Robinson et al., 2014). Textbooks are generally accepted as an indispensable part and a valuable source for educational activities because they offer students a great variety of new and potentially interesting facts and usher in numerous experiences (Dreyfus, 1992; Chambliss \& Calfee, 1998; Çimer, 2004; Mohammadia \& Abdib, 2014; Robinson et al., 2014). Not only do textbooks influence what and how students learn, but also what and how teachers teach (Mahmood, 2011). Sosniak and Perlman (1990) indicate that the power of textbooks lies in their ability to serve as resources that introduce readers to worlds that are not immediately obvious or cannot be experienced directly. In particular, they can organize ideas and information in order to structure teaching and learning, guiding students' understanding, thinking, and feeling. Textbooks are no doubt essential in terms of both helping teachers and supporting students' learning (Özdemir \& Pusmaz, 2007).

The fact that textbooks act as basic material in education and training at schools requires textbooks to be prepared more qualitatively and sufficiently (Çimer, 2004). Designing sufficient and high-quality textbooks will orient learning activities to students' learning needs and also provide them with various benefits (Semerci, 2004). 
Trowbridge and Bybee (1996) believe that students generally feel more comfortable with a textbook than without one as they emphasize important concepts, direct independent learning activities, and present learning goals for the study of a particular science topic. Ogan-Bekiroglu (2007) states that "well-designed texts present information and ideas in an organized manner; hence, students can relate to them meaningfully. Textbooks may also improve thinking and reinforce learning in science provided that they meet the student's learning needs. In other words, if selected and used properly, textbooks can help students to accommodate complex science inquiry lessons." (p. 600-601). Moreover, appropriately prepared textbooks will both draw students' attention to lessons and affect their success in lessons positively (Korkmaz, 2006). Since textbooks are seen as an important part in the instructional process, they must be designed to meet the needs and the requirements, expectations, and interests of the community, teachers, and students. Therefore, it is recommended that textbooks contain several teaching activities that provide students with opportunities to learn actively without passively absorbing knowledge from the teacher or the textbook itself directly (Ünsal \& Güneş, 2003). They should encourage students to learn actively through thinking, investigating, and analyzing the provided information, creating new and original meanings and knowledge, and taking on responsibilities (Delice, 2006; Kabapınar, 2006; Özatalay, 2007; Pop-Păcurar \& Ciascai, 2010). Given the importance of published curriculum materials in teaching and learning, which is mainly in the form of textbooks in many developing countries including Pakistan, the establishment of an effective method of evaluation of these materials by their potential users and experts is an important goal (Mahmood, 2011).

Many changes have been made to the education system in Turkey in an attempt to improve the quality of teaching and learning in classes. As a result of some reforms in the Turkish Education System, new approaches in teaching and learning, such as the constructivist learning theory, have been initiated (Kılıç, 2013). In Turkey, curriculum policies have been attempting to incorporate constructivist learning theory from pre-school onwards to secondary schools and teacher education faculties. In these contexts, redesigning textbooks is also important, as they are vital instruments in this changing educational practice and must be adopted to meet the current needs of teachers and students. In other words, improvements in the education system and policies, new teaching methods, and alternative assessment methods should be reflected in the content and design of the textbooks. Reviewing the textbooks in this direction and then redesigning them by addressing their limitations will certainly improve their quality and features and lead to them serving the best educational purposes. In this regard, it is necessary to examine the suitability of biology textbooks incorporating constructivist learning theory from not only expert perspectives but that of students.

Almost two decades ago, Fullan (1991, p70) posed the question, "What would happen if we treated the student as someone whose opinion mattered?" This question alerted educational researchers and educators not only about their failure to listen intelligently but also to the radical cultural change that might ensue. In fact, many researchers reported that investigating student views has been generally neglected in educational research and overlooked by teachers, schools, and policy makers (Beynon, 1985; SooHoo, 1993; Roth \& Roychoudbury, 1994; Morgan \& Morris, 1999; Heipp, 2016). Instead, the focus has been on teachers' views and practices in science teaching because they have been considered to be significantly worthier of attention than students' views. However, many researchers have advocated listening to student voices as they are valuable data sources for improving the quality of teaching in schools, as students are generous commentators and insightful critics of the teaching and learning activities they experience (Stenhouse, 1975; SooHoo, 1993; Nieto, 1994; Macbeath, Schratz, Meurat, \& Jakobsen, 2000; Macbeath \& Mortimore, 2001). Researchers also argue that what students say about teaching, learning, and schooling is not only worth listening to, but provides an important - perhaps the most important - foundation for thinking about ways of improving teaching, learning, and schools. For example, Phoenix (2000) asserts that student views on teaching may reflect the ways in which students learn best. In addition, even though Beynon (1985) does not consider student views as completely fair, trustworthy, or valid judgements of effectiveness, he nevertheless emphasizes that their perceptions do have considerable value as a revealing source of feedback on teacher performance. Furthermore, Stenhouse (1975) claims that students will do better in school if teachers listen to them and demonstrate that they are prepared to take their ideas seriously. MacBeath et al. (2000) reported that schools that have acknowledged the importance of student views have been able to make a substantial contribution to classroom management, to learning and teaching, and to the school as a social and learning place. Similarly, MacBeath \& Mortimore (2001) state that students may demonstrate maturity and insights that are valuable to the school and that combined with teachers, they can play a significantly more active, participative, and reciprocal role, in the development of schools. Thus, all the above-mentioned literature suggests that student views alone or combined with teacher views should be taken into account seriously in discussions concerning improvements in learning and teaching in schools. When evaluating and selecting textbooks in schools, rather than merely seeking teachers' and administrators' views on 
the quality of textbooks, asking students about their views on textbooks would be a valuable source to improve the quality of textbooks. Therefore, this study aimed to determine secondary school students' views about their ninth grade biology textbook in terms of its contents, learning and teaching activities, assessment and evaluation activities, and physical design in order to contribute to the processes of textbook design.

\section{Methodology}

Fan, Zhu, \& Miao (2013) assert that textbook analysis is a broad term primarily referring to the analysis of a single textbook or a series of textbooks. Such analysis often focuses on how a topic or topics are treated or how a particular idea or aspect of interest is reflected in the textbooks, and includes an analysis of different series of textbooks from the same country or more frequently, different countries, often with a focus on identifying their similarities and differences. In the present study, based on the students' views, the complete ninth grade biology textbook was analyzed in terms of its content, learning and teaching activities, assessment and evaluation activities, and physical design. The study data were obtained by using a quantitative research approach (Lincoln and Guba, 1985; Bell, 1993; Creswell, 1994; Anderson \& Arsenault, 1998; Cohen \& Manion, 2000), which involved analyzing the quantitative data obtained via questionnaires that offer a general perspective of the students' views of the textbook. Therefore, the study adopted survey method as a research design (Creswell, 2014).

\subsection{Research Sample}

The sample of the research included a total of 751 students studying at 9 high schools in the city of Trabzon, a city on the Black Sea coast of northeastern Turkey. A total of 3 classes from each school were included in the study. All the students in the 27 classes participated in the study. Of the sample, $55.8 \%$ were girls (419), while the remaining $54.2 \%$ were boys (332).

\subsection{Data Collection}

A questionnaire developed by two researchers was used to collect data from the students. In creating the questionnaire and its items, the following were taken into consideration: studies on textbooks; questionnaires used for assessment of textbooks for different subject matters (Çepni, Ayvacı \& Keleş, 2001; Çepni, Gökdere \& Taş, 2001; Mülayim \& Soran, 2002; Çimer, 2004, Ceyhan \& Yiğit, 2005; Çoban et al., 2006; Delice, 2006; Demirel \& Kıroğlu, 2006; Kabapınar, 2006; Kavaz, 2006; Adıbelli, 2007; Atıcı et al., 2007; Kete \& Acar, 2007; Ogan Bekiroğlu, 2007; Özay \& Hasenekoğlu, 2007; Özsoy, 2007; Yıldırım, 2007; Pop-Păcurar \& Ciascai, 2010); and constructivist learning approach and its principles, and literature on the related features in a textbook (Kılıç, 2001; Jones \& Araje, 2002; Kabapınar, 2003; Köseoğlu et al., 2003; Akpınar \& Ergin, 2004; Duman, 2004; Akpınar \& Ergin, 2005; Ayar, 2006; Saygın et al., 2006; Arslan, 2007; Kirişçioğlu, 2007; Demirel, 2008; Kü̧̈üközer, Bostan, Kenar, Seçer \& Yavuz, 2008; Yaşar \& Gültekin, 2009; Kılıç, 2013; Mohammadia \& Abdib, 2014). An item pool categorized into four main sections, namely, content, learning and teaching activities, assessment and evaluation, and physical design of a textbook, was created. The content validity of a scale composed of 86 items created from this item pool was examined by two experts in biology education from Karadeniz Technical University in the city of Trabzon, Turkey. In addition, four open-ended questions were included in the questionnaire in order for the students to express their own views about the biology textbook freely.

The first draft of the questionnaire was piloted with 76 ninth-grade students studying from a high school that was not included in the study sample. The findings obtained from the pilot scheme were reviewed by two lecturers and two teachers of biology and the findings were incorporated into the final questionnaire. The questionnaire consisted of two sections, A and B. Section A included questions on students' personal information, while Section B included questions seeking to understand their opinions about the biology textbook, responses to which were scored on a 5-point Likert scale (1: Strongly Disagree, 2: Disagree, 3: Undecided, 4: Agree, 5: Strongly Agree). Section B was divided into 5 separate subsections, namely content (26 items), learning-teaching activities (30 items), assessment and evaluation activities (15 items), physical design (14 items), and 4 open-ended questions.

As the students completed using the textbook and engaged the most with it by the end of the year, the data collection was conducted at the end of the spring semester. The researchers visited each school involved in the study and three classes from the ninth grade of each school were randomly chosen. The questionnaire was administered to the students of these classes, before which the students were informed about how to respond to the questions in the questionnaire and asked whether or not they were volunteers in participating in the study in order to seek their consent for being a participant. 


\subsection{Data Analyses}

The quantitative data obtained in the form of responses to the questionnaire were analyzed using the SPSS 15.0 software package. Before performing the quantitative analysis, the 5-point Likert scale (1: Strongly Disagree, 2: Disagree, 3: Undecided, 4: Agree, 5: Strongly Agree) was collapsed into a 3-point scale (1: Disagree, 2: Undecided, 3: Agree) in order to offer a clearer and factual interpretation of the findings. The Cronbach's alpha formula was used to identify the reliability of the questionnaire, and the reliability coefficient was determined as 0.94 .

The data obtained from the open-ended questions were analyzed qualitatively and classified under content, learning-teaching activities, assessment-evaluation, and physical design. In the findings and discussion section below, the findings related to the questionnaire items and the responses to the open-ended questions are discussed together where appropriate.

\section{Findings and Discussion}

\subsection{Students' Views about the Contents of the Ninth Grade Biology Textbook}

The students' responses to the questionnaire items on the contents of the ninth grade textbook are provided in Table 1. Overall, the students responded positively about the contents of the textbook. They found the level of the textbook appropriate to their learning capacity and level. For example, $69 \%$ of the students disagreed with the item "The topics in the textbook are not presented according to the class level." However, $50 \%$ of them agreed with the item "The topics in the textbook are appropriate to our learning level." According to the table, the topics or subject were connected to each other and the other disciplines as well in forming the content of the textbook. More than $40 \%$ of the students agreed with the following items: "When necessary, the topics are connected with those in other subjects (Physics, Chemistry etc.) " (45\%), "The topics in the textbook are connected to each other" (46\%), and "Topics are arranged in a logical sequence" (49\%). The students also agreed that there was no misinformation in the textbook by disagreeing with the item, "I often encounter inaccurate information in the textbook" (67\%). The constructivist learning approach does not require providing detailed knowledge directly to the students but demands that students themselves construct knowledge or their learning by constructing or combining their existing knowledge and newly acquired knowledge through searching, analysis, and interpretation. Therefore, textbooks should contain less detailed information for students but more activities or questions for them to engage intellectually to learn. They should guide students to discover new knowledge and construct on their existing knowledge (Ünsal \& Güneş, 2003; Özmen, 2004; Kiriş̧̧ioğlu, 2007; Küçüközer et al., 2008; Pop-Păcurar \& Ciascai, 2010; Kılıç, 2013; Mohammadia \& Abdib, 2014).

Table 1. Students' views about the contents of the ninth grade biology textbook $(\mathrm{n}=751)$

\begin{tabular}{|c|c|c|c|c|}
\hline & Items (1: Disagree; 2: Undecided, 3: Agree) & $1(\%)$ & $2(\%)$ & $3(\%)$ \\
\hline 1 & When necessary, the topics are connected with those in other subjects (Physics, Chemistry etc.). & 19 & 37 & 45 \\
\hline 2 & Tables, graphs, or figures provided in the textbook help us acquire and interpret information. & 17 & 25 & 58 \\
\hline 3 & Topics are discussed in a detailed manner. & 31 & 31 & 38 \\
\hline 4 & The topics in the textbook are connected to each other. & 18 & 36 & 46 \\
\hline 5 & The topics in the textbook are taught using brief and concise information. & 34 & 32 & 34 \\
\hline 6 & When presenting the topics, current events are used as examples. & 25 & 29 & 46 \\
\hline 7 & The topics in the textbook are not presented according to the class level. & 69 & 16 & 15 \\
\hline 8 & The textbook is sufficient for us to learn basic biological concepts. & 31 & 33 & 36 \\
\hline 9 & Detailed definitions of biological concepts or terms are provided in the textbook. & 30 & 35 & 35 \\
\hline 10 & Essential knowledge related to the topics in the textbook is distinctly emphasized. & 33 & 33 & 35 \\
\hline 11 & I have to use other resources because the topics in the textbook are superficially presented. & 26 & 25 & 49 \\
\hline 12 & $\begin{array}{l}\text { I can use the knowledge I have acquired from the textbook to solve biology-related problems that I } \\
\text { encounter in my daily life. }\end{array}$ & 28 & 37 & 35 \\
\hline 13 & I often encounter inaccurate information in the textbook. & 67 & 19 & 14 \\
\hline 14 & The topics are enriched with examples from daily life. & 23 & 36 & 41 \\
\hline 15 & The historical development of biology is also discussed in the textbook. & 33 & 33 & 34 \\
\hline 16 & The textbook includes numerous definitions. & 40 & 35 & 25 \\
\hline 17 & The number of examples for each topic is adequate & 33 & 31 & 36 \\
\hline 18 & Summaries are provided at the end of sections. & 69 & 19 & 12 \\
\hline 19 & Descriptions are provided under pictures, graphics, figures, and tables. & 16 & 29 & 54 \\
\hline 20 & The textbook includes excessive and unnecessary knowledge that I will not use in my daily life. & 37 & 34 & 29 \\
\hline 21 & At the end of a topic, there are additional resources that allow us to obtain more detailed information. & 55 & 28 & 17 \\
\hline
\end{tabular}




\begin{tabular}{|c|c|c|c|c|}
\hline 22 & The topics in the textbook are appropriate to our learning level. & 20 & 30 & 50 \\
\hline 23 & The information provided in the textbook is up to date. & 24 & 39 & 37 \\
\hline 24 & Pictures, graphs, figures, and tables in the textbook are appropriate to the topics. & 9 & 20 & 70 \\
\hline 25 & Topics are arranged in a logical sequence. . & 20 & 31 & 49 \\
\hline 26 & $\begin{array}{l}\text { At the end of each topic, reading texts are provided in the textbook that make it easy to establish a } \\
\text { connection with current events. }\end{array}$ & 34 & 30 & 37 \\
\hline
\end{tabular}

Table 1 also reveals that pictures, graphs, figures, and tables in the textbook had favorable features according to the students. Of the students, $58 \%$ agreed with the item "Tables, graphs, or figures provided in the textbook help us acquire and interpret information." According to $54 \%$ of the students, the textbook provided descriptions under pictures, graphs, figures, and tables. $70 \%$ of them agreed with the item "Pictures, graphs, figures, and tables in the textbook are appropriate to the topics." In addition, the students appreciated that the textbook contained daily life events or examples. Of the students, $46 \%$ agreed with the item, "When presenting the topics, current events are used as examples," whilst $41 \%$ of them agreed with the item "The topics are enriched with examples from daily life." Furthermore, 91\% of the students (681) stated in their responses to the open-ended questions that they found the textbook to be adequate in terms of visual materials and 260 of them emphasized that they found the subjects having pictures, graphs, schemas, and tables to be more attractive. All these findings suggest that the students were satisfied with the many different visual materials in the textbook and indicate that textbooks containing visuals help students learn and understand subjects easily and attract their attention. Several researchers have discussed visuals in textbooks. Gilbert (2003) stated that "visual representations, diagrams especially, are important in science learning from textbooks; however, their impact may be constrained by the learner's ability to construct a mental model from them" (p. 6). Textbooks adopting constructivist learning approach help students' learning and interpretation skills and motivate them to participate in the lessons (Kabapınar, 2003; Dervişoğlu, Yaman \& Soran, 2004; Küçükahmet, 2004; Kılıç, 2006; Kete \& Acar, 2007; Özay \& Hasenekoğlu, 2007). For these reasons, textbooks should have appropriate visual materials in order to attract students' attention, in order to motivate and help them to learn more.

Information in textbooks plays a pivotal role in shaping up the process of classroom teaching and learning, designing of assessment system, and evaluation of students' ability to retain and reproduce the information presented in textbooks (Mahmood, 2011). In terms of the contents of the textbook, almost half of the students (49\%) indicated that the topics in the textbook were not described in detail by agreeing with the item "I have to use other resources because the topics in the textbook are superficially presented." Consistent with this finding, relatively lesser number of students agreed with the following items: "Topics are discussed in a detailed manner," (38\%), "Detailed definitions of biological concepts or terms are presented in the textbook," (35\%) and "The textbook is sufficient for us to learn basic biological concepts" (36\%). Furthermore, $40 \%$ of them disagreed with the item "The textbook includes numerous definitions." All these responses might indicate that the students did not consider the textbook's content rich enough to help them prepare for national university entrance exams. However, $92 \%$ (688) complained about the manner of presentation of the content in their written responses to the open-ended questions. For example, they wrote that "The textbook contains detailed texts written using long and complex sentences. While one topic was limited to two pages in the reference book, the same took up ten pages in the textbook because of irrelevant sentences. The text contained overly long and complex sentences." Such issues decreased the readability and increased the difficulty of the topics in the textbook for the students. In addition, 452 students did not want unnecessarily long and detailed knowledge in the textbook as exemplified via the following response to the open-ended question: "Topics must be provided summaries and described in a clear and comprehensible manner. Teaching must be more informational. Topics, questions, and activities must be appropriately allocated. Questions must not be asked during teaching. The topics must be itemized, and the important points must be emphasized." The students expected the key points of the topics to be listed at the end of sections as summaries or short notes. However, while almost $50 \%$ of the students' written statements reported the absence of any summary at the end of the sections, $69 \%$ of the students disagreed with the item "Summaries are provided at the end of sections." Of the students, $55 \%$ disagreed with the item "At the end of a topic, there are additional resources that allow us to obtain more detailed information" (Table 1). The students expected the key points of the topics, which were asked in the exams, particularly university entrance exams, be explicitly mentioned in the textbook or told, even though providing relevant information directly in this manner is not entirely consistent with constructivist learning theory. Therefore, they preferred to use other reference books in order to learn and become familiar with more detailed knowledge related to biology (Çimer, 2004). 
Summarizing, it can be said that the students were overall satisfied with the contents of the ninth grade biology textbook. However, they found the text detailed, messy, lengthy, and confusing. The textbook was deemed to be adequate in terms of the number and quality of visual materials.

\subsection{Students' Views about the Learning-Teaching Activities in the Ninth Grade Biology Textbook}

Table 2 presents the responses to the questionnaire items on the learning and teaching activities in the textbook. The students were in general dissatisfied with the learning-teaching activities in the textbook. More than $40 \%$ of the students found the textbook insufficient in terms of teaching and learning activities related to daily life. For example, they indicated that the textbook did not offer problems to solve that were related to daily life (40\%) or contain activities that allowed them to look at daily life problems from different perspectives while trying to solve them (37\%). Additionally, $44 \%$ of them indicated that the activities in the textbook were not focused on solving daily life problems or situations. In addition, $43 \%$ of the students indicated that the textbook did not serve as a guide book that showed them how to use the knowledge, skills, and experiences that they had acquired from the lessons. All of these indicate that teaching and learning activities in the textbook did not manage to connect its contents with daily life or help students to make this connection effectively. According to the constructivist approach, learned information must be functional and capable of being implemented in practice so that students can have clarity about the field of application. Moreover, the chosen examples chosen must offer solutions to problems encountered in daily life (Delil \& Güneş, 2007; Küçüközer et al., 2008). Schaefer (1979) argues that if the concepts taught at school are not related to students' everyday lives, students may fail to use them adequately outside the school. Therefore, their knowledge may remain in the form of acquired isolated knowledge "packages." Effective learning requires students to apply newly acquired concepts or skills to different contexts (Wallberg, 1991; Good \& Brophy, 1994; Gallagher, 2000; Yip, 2001). Therefore, textbooks should include various teaching and learning activities combining scientific knowledge with students' daily life or events.

The students agreed that the teaching and learning activities in the textbook encouraged them to rethink and interpret the knowledge they had acquired. For example, $42 \%$ of the students agreed with the item "Activities and questions in the textbook stimulate us to think". According to the constructivist learning theory, students must actively take a part in learning under natural conditions in order to engage in significant learning instead of memorization and gain the ability to structure information (Özerbaş, 2007). For this reason, the textbook must contain activities and projects that enable students to benefit from their life experiences, use their previous knowledge, structure new information by offering their own interpretation, perform research, and think critically and inventively by assuming responsibility (Kabapınar, 2003; Köseoğlu, Atasoy \& Kavak, 2003; Ünsal \& Güneş, 2004; Delice, 2006; Kabapınar, 2006; Özatalay, 2007; Kılıç \& Seven, 2008; Küçüközer et al., 2008).

Table 2. Students' views about the learning-teaching activities in the ninth grade biology textbook $(\mathrm{n}=751)$

\begin{tabular}{|c|c|c|c|c|}
\hline No & Items (1: Disagree; 2: Undecided, 3: Agree) & $1(\%)$ & $2(\%)$ & $3(\%)$ \\
\hline 1 & The textbook offers problems to solve that are related to daily life. & 40 & 38 & 23 \\
\hline 2 & Activities and questions in the textbook stimulate us to think. & 26 & 33 & 42 \\
\hline 3 & Teachers' role in the activities is minimal. & 38 & 28 & 34 \\
\hline 4 & The textbook includes activities that allow us to participate in the lesson actively. & 35 & 28 & 37 \\
\hline 5 & Activities in the textbook encourage us to take responsibility for our learning. & 27 & 26 & 47 \\
\hline 6 & Activities in the textbook offer us different learning environments. & 28 & 31 & 41 \\
\hline 7 & We can easily carry out the laboratory activities given in the textbook. & 52 & 26 & 22 \\
\hline 8 & Activities in the textbook are suitable for our ability level. & 22 & 34 & 44 \\
\hline 9 & The time allocated for conducting activities is not enough. & 36 & 26 & 38 \\
\hline 10 & Activities in the textbook require us to work in groups. & 30 & 27 & 43 \\
\hline 11 & $\begin{array}{l}\text { The textbook includes preparatory questions and activities that attempt to gauge our existing } \\
\text { knowledge before the beginning of each unit or topic. }\end{array}$ & 32 & 26 & 43 \\
\hline 12 & The activities in the textbook enable us to acquire knowledge without the teacher's help. & 43 & 31 & 27 \\
\hline 13 & The provided experiments facilitate our understanding of the topics & 33 & 31 & 36 \\
\hline 14 & The textbook contains activities or questions requiring us to design our own experiments. & 45 & 30 & 26 \\
\hline 15 & The activities in the textbook allow us to learn other students' opinions and ideas on the topics. & 35 & 32 & 33 \\
\hline 16 & The activities in the textbook reinforce our understanding and learning of the topics. & 26 & 30 & 45 \\
\hline 17 & The textbook includes such activities as field visits, observation, and investigations. & 40 & 29 & 31 \\
\hline 18 & The activities in the textbook enable us to express our ideas and opinions related to the lesson. & 34 & 33 & 33 \\
\hline 19 & $\begin{array}{l}\text { The textbook includes activities that allow us to look at daily life problems from different } \\
\text { perspectives while trying to solve them. }\end{array}$ & 37 & 36 & 27 \\
\hline 20 & $\begin{array}{l}\text { The textbook serves as a guide book that shows us how to use the knowledge, skills, and experiences } \\
\text { that we have acquired from the lessons. }\end{array}$ & 43 & 33 & 25 \\
\hline
\end{tabular}




\begin{tabular}{|c|c|c|c|c|}
\hline 21 & Questions and activities in the textbook encourage us to think about the topics and interpret them. & 27 & 34 & 40 \\
\hline 22 & The activities in the textbook allow us to discuss the subjects in class. & 37 & 30 & 33 \\
\hline 23 & The activities in the textbook are focused on solving daily life problems or situations. & 44 & 35 & 22 \\
\hline 24 & The teacher must describe the activities in the textbook. & 33 & 27 & 40 \\
\hline 25 & The activities in the textbook encourage us to learn the subjects by researching other sources. & 31 & 33 & 36 \\
\hline 26 & $\begin{array}{l}\text { The textbook contains various activities that enable us to present our knowledge and skills in } \\
\text { different ways. }\end{array}$ & 35 & 37 & 27 \\
\hline 27 & The methods to conduct experiments are described in detail in the textbook. & 36 & 32 & 32 \\
\hline 28 & The textbook includes such activities as structured grids or componential analysis tables. & 37 & 32 & 31 \\
\hline 29 & The topics in the textbook are arranged in an increasing order of difficulty. & 44 & 29 & 27 \\
\hline 30 & Application instructions for the activities are provided. & 35 & 34 & 31 \\
\hline
\end{tabular}

Çimer (2004) asserts that effective instructional approaches have to be based on what is already known by the learner. The evaluation of learners' pre-existing knowledge is important for teachers to plan subsequent teaching activities and help students link the new material to what they already know. In terms of these issues, more than $40 \%$ of the students also agreed with many items in the questionnaires. For example, they indicated that the teaching and learning activities were suitable for their ability level (44\%), encouraged them to take responsibility for their learning (47\%), offered different learning environments $(41 \%)$, and required them to work in groups (43\%). The textbook activities also attempted to explore students' existing ideas as well. Of the students, $43 \%$ agreed with the item, "The textbook includes preparatory questions and activities that attempt to gauge our existing knowledge before the beginning of each unit or topic." Determining students' existing ideas and conceptions has been recognized as an important variable in science teaching and a necessary part of formulating teaching strategies (Ausubel, 1968; Driver, 1983; Osborne \& Wittrock, 1983; Novak \& Gowin, 1984; Duit \& Treagust, 1998; Tytler, 2002; Franke, Scharfenberg \& Bogner, 2013; Campbell, Schwarz, \& Windschitl, 2016; Larkin, 2017). Hipkins et al. (2002) argue that science teaching becomes effective when the existing ideas, values, and beliefs that students bring to a lesson are elicited, addressed, and linked to their classroom experiences at the beginning of a teaching program. Additionally, $45 \%$ of the students reported that activities in the textbook reinforced their understanding and learning of the topics. All of these findings reflect compliance with the constructivist learning approach and student-centered teaching.

However, the students also expressed strong disagreements with the teaching and learning activities in the textbook. Many students implied that students may not use or operate the teaching and learning activities by themselves without the teacher's help. For example, $52 \%$ of them disagreed with the item, "We can easily carry out laboratory activities given in the textbook," while at least $40 \%$ of them disagreed with the items "The activities in the textbook enable us to acquire knowledge without the teacher's help" and "The teacher must describe the activities in the textbook." They also indicated that the textbook did not include activities or questions requiring them to design their own experiments (45\%) and such activities as field visits, observation, and investigations (40\%). These imply that even though the textbook were created in accordance with constructivist learning theory and a student-centered approach, some elements continued to reflect teacher-centered approaches. This is clearly evident in the students' responses to the item, "Teachers' role in the activities is minimal." While $38 \%$ of the students disagreed with this item, only $34 \%$ of them agreed. However, textbooks should offer opportunities for students to learn by themselves including gaining, processing, evaluating, and integrating new bits of information and to acquire the ability to apply these competences in various situations and contexts including learning and problem solving at home, in an educational process, at work, and in a society (Čeretková, Šedivý, Molnár, \& Petr, 2008).

According to $44 \%$ of the students, the topics in the textbook were not arranged in an increasing order of difficulty. Almost half of the students (47\%) explained that the activities encouraged them to take responsibility for their learning, while $37 \%$ stated that the textbook included activities that allowed them to participate in the lesson actively. Overall, in this section, more than $40 \%$ of the students reported disagreement with the questionnaire items in terms of teaching and learning activities. Their responses appear to indicate that the teaching and learning activities or processes of the textbook continue to reflect teacher-centered implementations.

\subsection{Students' Views about the Assessment and Evaluation Activities in the Ninth Grade Biology Textbook}

The students' opinions about the assessment and evaluation activities of the textbook are provided in Table 3. Čeretková et al. (2008) asserts that a textbook must contain a sufficient number of standard as well as non-standard problems or tasks. The problems or tasks provided in the textbook should create sufficient conditions for a student to gain experience. Problems with sample solutions provided in the textbook influence the 
understanding and acquisition of knowledge related to biology while simultaneously functioning as the means of teaching the methods for solving biology problems. Therefore, the students were asked whether the textbook contained suitable assessment and evaluation activities.

Table 3. Students' views about the assessment and evaluation activities in the ninth grade biology textbook $(\mathrm{n}=751)$

\begin{tabular}{|c|c|c|c|c|}
\hline No & Items (1: Disagree; 2: Undecided, 3: Agree) & $1(\%)$ & $2(\%)$ & $3(\%)$ \\
\hline 1 & Preparatory activities related to the topics stimulate us to think and make inquiries. & 31 & 33 & 36 \\
\hline 2 & $\begin{array}{l}\text { The textbook contains questions or activities that aim to clarify the level of our existing knowledge at } \\
\text { the beginning of a new topic. }\end{array}$ & 35 & 32 & 34 \\
\hline 3 & Questions in the textbook are not sufficient to reinforce our learning and understanding of the topics. & 35 & 30 & 35 \\
\hline 4 & The textbook contains questions that prompt us to rethink and interpret the relevant information. & 26 & 33 & 41 \\
\hline 5 & The textbook contains evaluative questions at the end of each topic or section. & 12 & 16 & 72 \\
\hline 6 & $\begin{array}{l}\text { The questions provided at the end of each topic or section are not adequate to evaluate if we have } \\
\text { understood the topic. }\end{array}$ & 39 & 25 & 36 \\
\hline 7 & The textbook contains questions that encourage us to express our own ideas and experiences. & 32 & 36 & 32 \\
\hline 8 & Performance tasks and assignments attract our attention. & 50 & 25 & 25 \\
\hline 9 & Preparatory questions or activities at the beginning of the topics attract our attention. & 38 & 31 & 32 \\
\hline 10 & The textbook contains activities enabling us to assess our own learning. & 36 & 33 & 31 \\
\hline 11 & $\begin{array}{l}\text { The textbook contains different types of questions seeking to evaluate if we have understood the } \\
\text { subjects. }\end{array}$ & 32 & 32 & 37 \\
\hline 12 & The textbook contains performance tasks that we can mentioned in our portfolios. & 42 & 29 & 29 \\
\hline 13 & $\begin{array}{l}\text { The textbook contains various questions, tasks, or assignments that encourage us to conduct research } \\
\text { and investigation. }\end{array}$ & 28 & 31 & 42 \\
\hline 14 & $\begin{array}{l}\text { The textbook contains questions requiring us to interpret the tables, graph, or pictures included within } \\
\text { a topic. }\end{array}$ & 30 & 33 & 37 \\
\hline 15 & We generally face difficulties in answering the questions in the textbook. & 49 & 31 & 20 \\
\hline
\end{tabular}

In general, the students had balanced views about the assessment and evaluation activities of the biology textbook. However, more than $40 \%$ of the students reported strong views on some items. For example, the students indicated that the textbooks have different types of questions for measuring their learning and understanding. They (49\%) agreed that they did not face difficulties in answering the questions in the textbook. This might imply that questions in the textbook were appropriate for the students' learning level. Of the students, $41 \%$ indicated that the textbook contained questions that prompted them to rethink and interpret the relevant information, while $42 \%$ of them indicated that the textbook contained various questions, tasks, or assignments that encouraged them to conduct research and investigation. These responses might imply that the questions created opportunities for the students to think, investigate, and interpret knowledge and thus, facilitate their learning and understanding.

Nearly $40 \%$ of the students reported that preparatory activities related to the subjects stimulate us to think and make inquiries. However, they disagreed with the item, "Preparatory questions or activities at the beginning of the topics attract our attention" (38\%). This might imply that the included preparatory questions or tasks were not efficient enough to stimulate students to rethink and investigate the topics prior to the classes. On the other hand, a significant majority of the students $(72 \%)$ agreed that the textbook contained evaluative questions at the end of each topic or section, and 39\% agreed that the questions provided at the end of each topic or section were adequate to evaluate if they had understood the topic.

Performance tasks require students to create products or perform tasks to demonstrate their mastery over particular skills. Performance tasks range from short activities taking only a few minutes to projects culminating in new products for others inside and outside of the classroom. While $50 \%$ of the students indicated that performance tasks or assignments did not attract their attention, $42 \%$ of them disagreed with the item, "The textbook contains performance tasks that we can mentioned in our portfolios." These responses might imply that the textbook did not offer good quality performance tasks or assignments. Constructivist learning environments treat performance tasks or assignments as indispensable tools to assess and evaluate students' actual performance and development, implying that complying textbooks should include performance tasks or assignments. Overall, the students in general were satisfied with the assessment and evaluation activities in the textbook, although they were dissatisfied with the preparatory questions or tasks and the performance tasks or assignments. 


\subsection{Students' Views about the Physical Design of the Ninth Grade Biology Textbook}

The students' views about the physical design of the textbook are provided in Table 4. Compared to the other categories, the highest agreement between students was indicated on questions related to physical design. Almost all the items in this section of the questionnaire had high agreement scores. For example, $70 \%$ of the students indicated an agreement with the item "The letterpress of the textbook is open, clear, and comprehensible," while $60 \%$ of them disagreed with the item "There are too many typographical errors in the textbook." Of the students, over 50\% agreed with the items "Punctuation and spelling rules are strictly followed in the text" and "The textbook uses clear and intelligible language." Supporting to these views, also, $43 \%$ of them disagreed with the item "There are too many unfamiliar words in the textbook that we cannot understand". These views were also supported by the students' responses to the open-ended questions, such as "The print quality of the textbook is good" (34 students) and "Writings are quite clear, large-sized and comprehensible" (56 students).

Table 4. Students' views about the physical design of the ninth grade biology textbook $(\mathrm{n}=751)$

\begin{tabular}{|c|c|c|c|c|}
\hline No & Items (1: Disagree; 2: Undecided, 3: Agree) & $1(\%)$ & $2(\%)$ & $3(\%)$ \\
\hline 1 & Letterpress of the textbook is open, clear, and comprehensible. & 16 & 15 & 70 \\
\hline 2 & The size and weight of the textbook is appropriate for us to handle and use. & 24 & 24 & 53 \\
\hline 3 & The cover of the textbook is of good quality and is durable. & 38 & 28 & 34 \\
\hline 4 & Remarkable, motivating, and vibrant colors are used sufficiently in the textbook. & 34 & 24 & 42 \\
\hline 5 & The textbook uses language that has a natural flow and is comprehensible. & 31 & 31 & 39 \\
\hline 6 & The textbook is published on good quality paper. & 31 & 27 & 43 \\
\hline 7 & $\begin{array}{l}\text { Visual materials such as pictures, graphs, figures, and tables are placed appropriately in the } \\
\text { textbook. }\end{array}$ & 17 & 28 & 55 \\
\hline 8 & The textbook uses clear and intelligible language & 24 & 26 & 50 \\
\hline 9 & Punctuation and spelling rules are strictly followed in the text. & 16 & 24 & 60 \\
\hline 10 & There are too many typographical errors in the textbook. & 60 & 23 & 17 \\
\hline 11 & $\begin{array}{l}\text { The colors used of visual materials such as photos, pictures, and tables in the textbook are } \\
\text { attractive and interesting. }\end{array}$ & 30 & 27 & 43 \\
\hline 12 & There are too many unfamiliar words in the textbook that we cannot understand. & 43 & 31 & 27 \\
\hline 13 & Pictures, graphs, figures, and tables in the textbook are appropriate to our learning level. & 19 & 32 & 49 \\
\hline 14 & Long sentences are used for presenting information in the textbook. & 25 & 35 & 40 \\
\hline
\end{tabular}

The students acknowledged the fact that the textbook contained various and appropriate visual elements such as tables, figures, and pictures. Of the students, 55\% indicated that visual materials such as pictures, graphs, figures, and tables were placed appropriately in the textbook and $49 \%$ of them reported that pictures, graph, figures, or tables in the textbook were appropriate to their learning level. Similarly, examining the high school assessments across four science disciplines (i.e. biology, chemistry, earth science and physics), LaDue, Libarkin \& Thomas (2015) also found out that graphs, tables and diagrams were the only three types of visual representations that were common across these science disciplines. While $43 \%$ of them agreed that the colors used for visual materials such as photos, pictures, and tables in the textbook were attractive and interesting, $42 \%$ of them indicated that remarkable, motivating, and vibrant colors were used sufficiently in the textbook. Chen (2017) also reported that the integration of conceptually relevant visuals in textbooks enables individuals engage more in visualizing information, constructing mental models and interpreting content. Although $53 \%$ of the students agreed with the item "the size and weight of the textbook is appropriate for us to handle and use", 101 students wrote as a response to the open-ended questions in the questionnaire "The textbook is very thick and heavy. Therefore, I have difficulties in carrying it. It should be thinner and lighter." In general, the physical design of the textbook met the students' expectations. Supporting all these findings related to physical design of textbooks, Chen (2017) suggests that publishers should place priorities to explore the possibility of integrating more multimedia features to tap into more senses for readers like hearing, smell, taste and kinaesthesia. So, it might be created a learning environment where learners take the identity of scientists to engage in investigating problems, making hypotheses and evaluating evidence.

\section{Conclusions}

The study results indicated that a clear majority of the students had positive attitudes towards the textbook. The textbook was considered sufficient in terms of the quality and number of visual materials. Therefore, textbooks should have appropriate visual materials to attract students' attention in order to motivate and help them to learn better. 
The findings related to the presentation of the textbook topics revealed that the students were not satisfied with lengthy texts and excessive details, which is not appropriate to constructivist learning theory. The students expected key points pertinent to university examinations to be provided explicitly. The teaching and learning activities described in the textbook did not adequately relate to the students' daily life. According to the constructivist approach, learned information must be functional and should be transferable to practical applications. This requires textbooks contain activities that help the students connect their learning to their lived reality. However, the students also indicated that the teaching and learning activities encouraged them to take responsibility for their learning; offered different learning environments to them, required them to work in groups, and attempted to gauge their existing knowledge before starting each unit or topic. All these results are consistent with constructivist learning and a student-centered approach. Even though the textbook had been prepared in compliance with constructivist learning theory and a student-centered approach, some elements continued to reflect teacher-centered approaches. According to the findings, teachers in running continued to play a dominant role in teaching and learning activities and conducting experiments, thereby reducing students' control. Therefore, textbooks should offer opportunities for students to learn more by themselves.

The students were in general satisfied with the assessment and evaluation activities in the textbook even though the preparatory questions or tasks and the performance tasks or assignments were found to be unsatisfactory. The performance tasks or assignments in the textbook did not attract the students' interest. This might mean an inadequacy of qualified performance papers that could draw their attention.

The physical design of the textbook was found to be satisfactory, although responses to open-ended questions revealed a demand for a thinner book. Textbook should contain more colorful, attractive, and interesting visuals appropriate to the topics in the text and be thinner in size.

Overall, although the textbook was written with the purpose of carrying the principles of constructivist learning theory, it was found that it did not reflect many of those principles. Not conforming to these principles may not result in effective learning in schools. Therefore, textbook writers should definitely consider and adopt constructivist approach in preparing effective textbooks.

Concluding, it is imperative that textbook designers learn about students' views and preferences when designing and writing new textbooks in order to ensure effective learning. In order to investigate textbook design in further detail, future studies should be engage in more qualitative research and acquire an understanding of teachers' views as well. As the reliability coefficient was determined as 0.94 , it was proved that the questionnaire developed by the researchers in this study can be employed in order to determine features of effective textbooks. This study was limited to only the opinions of ninth graders about the ninth grade biology textbook. Further studies should also be carried out with higher levels students and textbooks as well in order to determine better the features of effective textbooks in biology and other subjects.

\section{References}

Adıbelli, S. (2007). Yeni Programa Göre Hazırlanan Lise 1 Fizik Ders Kitabının Eğitsel, Görsel, Dil ve Anlatım Yönünden İncelenmesi (Unpublished master's thesis). Selçuk University, Konya.

Akpınar, E., \& Ergin, Ö. (2004). Yapılandırmacı kuram ve fen öğretimi. Dokuz Eylül Üniversitesi Buca Eğitim Fakültesi Dergisi, 15, 108-113.

Akpınar, E., \& Ergin, Ö. (2005). Yapılandırmacı kurama dayalı fen öğretimine yönelik bir uygulama, Hacettepe Üniversitesi Ĕ̈itim Fakültesi Dergisi, 29, 9-17.

Anderson, G., \& Arsenault, N. (1998). Fundamentals of educational research. London: Falmer Press.

Arslan, M. (2007). Constructivist approaches in education. Ankara University Journal of Faculty of Educational Sciences, 40(1), 41-61.

Atıcı, T., Samancı, N. K., \& Özel, Ç. A. (2007). Ilköğretim fen bilgisi ders kitaplarının biyoloji konuları yönünden eleştirel olarak incelenmesi ve öğretmen görüşleri. Türk Eğitim Bilimleri Dergisi, 5(1), 115-131.

Ausubel, D. P. (1968). Educational psychology: A Cognitive View. New York: Holt, Reinhart and Winston.

Ayar, R. (2006). İlkögrretim Sosyal Bilimler Dersinde Hepimizin Dünyası Ünitesi İçin Yapılandırmacı Yaklaşıma Göre Ögretim Etkinliklerinin Geliştirilmesi (Unpublished master’s thesis). Gazi University, Ankara.

Bell, J. (1993). Doing your research project: a guide for first - time researchers in education and social science. Buckingham: Open University Press. 
Beynon, J. (1985). Initial Encounters in the Secondary School Sussing, Typing and Coping. London: Falmer Press.

Çakmak Ö., \& Hevedanlı, M. (2004). Biyoloji eğitiminde kavram haritalarının önemi ve diğer yöntemlerden farkı, XIII. Ulusal Eğitim Bilimleri Kurultayı, 6-9 Temmuz 2004. İnönü Üniversitesi, Eğitim Fakültesi, Malatya.

Campbell, T., Schwarz, C., \& Windschitl, M. (2016). What we call misconceptions may be necessary stepping-stones toward making sense of the world. Science Teacher, 83(3), 69-74. http://doi.org/10.2505/4/tst16_083_03_69

Çepni, S., Ayvacı, H. Ş., \& Keleş, E. (2001). Fizik ders kitaplarını değerlendirme ölçeği geliştirmek için örnek bir çalışma. Milli Ĕgitim Dergisi, 152, 27-33.

Çepni, S., Gökdere, M., \& Taş, E, (2001). Mevcut fen bilgisi kitaplarının bazı okunabilirlik formülleri ile değerlendirilmesi. Yeni Binyılın Başında Fen Bilimleri Eğitim Sempozyumu, 7-8 Eylül, Maltepe Üniversitesi Eğitim Fakültesi, İstanbul.

Čeretková, S., Šedivý, O., Molnár, J., \& Petr, D. (2008). The role and assessment of textbooks in mathematics education. Problems of Education in the 21st Century, 6, 27-37.

Ceyhan, E., \& Yiğit, B. (2005). Konu alanı ders kitabı incelemesi, Anı Yayıncılık, 3. Baskı, Ankara.

Chambliss, M. J., \& Calfee, R. C. (1998). Textbooks for learning: Nurturing children's minds. Malden, Mass: Blackwell Publishers.

Chen, X. (2017). A comparative study of visual representations in conventional, digitized and interactive high school science textbooks. Journal of Visual Literacy, 36(2), 107-122. https://doi.org/10.1080/1051144X.2017.1386388

Çimer, A. (2004). A Study of Turkish Biology Teachers' and Students' Views of Effective Teaching for Improving Teaching in Schools and Teacher Education (Unpublished EdD Thesis). Universty of Nottingham, United Kingdom.

Çınar, O., Teyfur, E., \& Teyfur, M. (2006). Ilköğretim okulu öğretmen ve yöneticilerinin yapılandırmacı eğitim yaklaşımı ve programı hakkındaki görüşleri. Eğitim Fakültesi Dergisi, 7(11), 47-64.

Çoban, A., Aktaş, M., \& Sülun, A. (2006). Biyoloji öğretim programının ÖSS soruları açısından değerlendirilmesi. Erzincan Eğitim Fakültesi Dergisi, 8(1), 23-35.

Cohen, L., \& Manion, L. (2000). Research methods in education (4th ed). London: Routledge. https://doi.org/10.4324/9780203224342

Creswell, J. W. (1994). Research design: qualitative and quantitative approaches. Thousand Oaks, CA: Sage Publications.

Creswell, J. W. (2014). Research Design: Qualitative, Quantitative and Mixed Methods Approaches (4th ed.). Thousand Oaks, CA: Sage.

Delice, A. (2006). Konu alanı ders kitabı incelemesi, öğrenme anlayışları işı̆̆ında ders kitabı hazırlama, PegemA Yayıncilık, 2. Bask1, Ankara.

Delil, A., \& Güleş, S. (2007). Yeni ilköğretim 6. sınıf matematik programındaki geometri ve ölçme öğrenme alanlarının yapılandırmacı öğrenme yaklaşımı açısından değerlendirilmesi. Uludă̆ Üniversitesi Ĕgitim Fakültesi Dergisi, 20(1), 35-48.

Demirel, Ö. (2008). Eğitim ve öğretimde çağdaş yaklaşımlar sempozyumu, yapılandırmacı ĕ̆itim, Harp Akademileri Basımevi, İstanbul, 15-32 s.

Demirel, Ö., \& Kıroğlu, K. (2006). Eğitim ve ders kitapları, konu alanı ders kitabı incelemesi, Ed. Özcan Demirel, Asım Kıroğlu, PegemA Yayıncılık, 2. Baskı, Ankara.

Dervişoğlu, S., Yaman, M., \& Soran, H. (2004). Ortaöğretim öğrencilerinin biyoloji dersine ve biyoloji konularına ilgilerinin belirlenmesi. Hacettepe Üniversitesi Ĕ̈itim Fakültesi Dergisi, 27, 67-73.

Dreyfus, A. (1992). Innovations and developments. Content analysis of school textbooks: the case of a technology-oriented curriculum. Taylor \& Francis Ltd., 1-11.

Driver, R. (1983). The pupil as scientist? Milton Keynes: Open University Press. 
Duit, R., \& Treagust, D. F. (1998). Learning in science-From behaviourism towards constructivism and beyond. In B. J. Fraser \& K. G. Tobin (Eds.), International Handbook of Science Education (pp 3-26). Dordrecht: Kluwer Academic Publishers. https://doi.org/10.1007/978-94-011-4940-2_1

Duman, B. (2004). Yapılandırmacı (constructive) öğrenme kuramları, ögrenme- ögrretme kuramlarl ve süreç temelli ögretim, Anı Yayınc1lık, Ankara, 53-72 s.

Fan, L., Zhu, Y., \& Miao, Z. (2013). Textbook research in mathematics education: development status and directions. ZDM Mathematics Education, 45, 633-646. https://doi.org/10.1007/s11858-013-0539-x

Franke, G., Scharfenberg, F.-J., \& Bogner, F. X. (2013). Investigation of Students' Alternative Conceptions of Terms and Processes of Gene Technology. ISRN Education. https://doi.org/10.1155/2013/741807

Fullan, M. (1991). The new meaning of educational change (2nd ed.). New York: Teachers College Press.

Gallagher, J. T. (2000). Teaching for understanding and application of science knowledge. School Science and Mathematics, 100(6), 310-318. https://doi.org/10.1111/j.1949-8594.2000.tb17325.x

Gilbert, J. K. (2010). The role of visual representations in the learning and teaching of science: An introduction. Asia-Pacific Forum on Science Learning and Teaching, 11(1), 1-19.

Good, T., \& Brophy, J. (1994). Looking in Classrooms (6th ed.). New York: Harper Collins.

Heipp, L. (2016). An exploration of student views on grading and learning in an alternative school setting. (Unpublished EdD Thesis), National College of Education National Louis University. Retrieved from https://digitalcommons.nl.edu/cgi/viewcontent.cgi?article=1236\&context=diss

Hipkins, R., Bolstad, R., Baker, R., Jones, A., Barker, M., Bell, B., ... Taylor, I. (2002). Curriculum, Learning and Effective Pedagogy: A Literature Review in Science Education. Wellington: Ministry of Education.

Jones, M. G., \& Araje, L. B. (2002). The impact of constructivism on education; language, discourse and meaning. American Communication Journal, 5(3).

Kabapınar, F. M. (2003). Oluşturmacı anlayış temelinde fen öğretimi ve fen ders kitapları: bir ders kitabı ünitesi olarak çözünürlük. Ĕgitim Araştırmaları Dergisi, 22, 139-149.

Kabapınar, Y. (2006). Konu alanı ders kitabı incelemesi, öğrenme anlayışları işığında ders kitabı hazırlama, PegemA Yayınc1lık, 2. Bask1, Ankara.

Kashi, F., Andreeva, N., \& Naeimi, A. (2015). The role of content analysis of biology textbooks in process of their teaching and designing in Iran. Proceedings of the 15th International Academic Conference, Rome, Italy, in April 14-17, 2015. International Institute of Social and Economic Sciences.

Kavaz, S. (2006). Analysis of high school physics textbooks (Unpublished master's thesis). Middle East Technical University, Ankara.

Kete, R., \& Acar, N., (2007). Lise 2 biyoloji ders kitapları üzerine öğrenci tutumlarının analizi. Kastamonu Ĕ̈itim Dergisi, 15(1), 221-230.

Kılıç, A., \& Seven, S. (2008). Konu alanı ders kitabı incelemesi, yeni programa uygun 7. Baskı, PegemA Akademi, Ankara.

Kılıç, Ç. (2013). Turkish Primary School Teachers' Opinions about Problem Posing Applications: Students, the Mathematics Curriculum and Mathematics Textbooks. Australian Journal of Teacher Education, 38(5), 144-155. http://dx.doi.org/10.14221/ajte.2013v38n5.10

Kılıç, D. (2006). Konu alanı ders kitabı incelemesi, ders kitabının öğretimdeki yeri. PegemA Yayıncılık, Ankara.

Kılıç, G. B. (2001). Oluşturmacı fen öğretimi. Kuram ve Uygulamada Eğitim Bilimleri Dergisi, 1, 7-22.

Kirişçioğlu, S. (2007). Ilköğretim 7. sınıf fen bilgisi dersi "basınç" konusunun yapılandırmacı öğrenme yaklaşımına dayalı ögretiminin akademik başarıya etkisi (Unpublished master's thesis). Pamukkale University, Denizli.

Korkmaz, M. (2006). Ortaögretim 9. Sinlf tarih ders kitaplarının niteliği hakkinda öğretmen ve öğrenci görüşlerinin değerlendirilmesi (Unpublished master's thesis). Marmara University, İstanbul.

Köseoğlu, F., Atasoy, B., \& Kavak, N., (2003). Yapılandırmacı öğrenme ortamı için bir fen ders kitabı nasıl olmalı. Asil Yayın Dağıtım, 1.Baskı, Eylül.

Küçükahmet, L. (2004). Öğretimde planlama ve değerlendirme, Nobel Yayın Dağıtım, Mart 15. Baskı, Ankara. 
Küçüközer, H., Bostan, A., Kenar, Z., Seçer, S., \& Yavuz, S., (2008). Altıncı sınıf fen ve teknoloji ders kitaplarının yapılandırmacı öğrenme kuramına göre değerlendirilmesi. Elementary Education Online, 7(1), 111-126.

LaDue, N. D., Libarkin, J. C., \& Thomas, S. R. (2015). Visual representations on high school biology, chemistry, earth science, and physics assessments. Journal of Science Education and Technology, 24, 818-834. https://doi.org/10.1007/s10956-015-9566-4

Larkin, D. (2017). Planning for the Elicitation of Students' Ideas: A Lesson Study Approach With Preservice Science Teachers. Journal of Science Teacher Education, 28(5), 425-443. https://doi.org/10.1080/1046560X.2017.1352410

Lincoln, Y. S., \& Guba, E. G. (1985). Naturalistic enquiry. Beverly Hills, CA: Sage Publishing.

MacBeath, J., \& Mortimore, P. (Eds.). (2001). Improving School Effectiveness. Buckingham: Open University Press.

MacBeath, J., Schratz, M., Meuret, D., \& Jakobsen, L. (2000). Self-evaluation in european schools: a story of change. London: Routledge. https://doi.org/10.4324/9780203165850

Mahmood, K. (2011). Conformity to quality characteristics of textbooks: the illusion of textbook evaluation in pakistan. Journal of Research and Reflections in Education, 5(2), 170-190.

Mohammadia, M \& Abdib, H. (2014). Textbook Evaluation: A Case Study. Procedia - Social and Behavioral Sciences, 98, 1148-1155. https://doi.org/10.1016/j.sbspro.2014.03.528

Morgan, C., \& Morris, G. (1999). Good teaching and learning: pupils and teachers speak. Buckingham: Open University Press.

Mülayim, H., \& Soran, H. (2002). Lise 1 Biyoloji ders kitapları ve haftalık ders saatleri hakkında öğrenci, öğretmen ve okul yöneticilerinin görüş ve önerileri. Hacettepe Üniversitesi Eğitim Fakültesi Dergisi, 23, 185-197.

Nieto, S. (1994). Lessons from students on creating a chance to dream. Harvard Educational Review, 64(4), 392-246. https://doi.org/10.17763/haer.64.4.4846361m306pl670

Novak, J. D., \& Gowin, D. B. (1984). Learning how to learn. Cambridge: Cambridge University Press. https://doi.org/10.1017/CBO9781139173469

Ogan-Bekiroglu. (2007). To What degree do the currently used physics textbooks meet the expectations? Journal of Science Teacher Education, 18, 599-628. https://doi.org/10.1007/s10972-007-9045-8

Osborne, R., \& Wittrock, M. (1983). Learning science: a generative process. Science Education, 67(4), 489-508. https://doi.org/10.1002/sce.3730670406

Özatalay, H. (2007). Ilköğretim 1.kademe Türkçe ögrretim programında öğrencilere kazandırılması hedeflenen temel becerilerin ders kitaplarında kullanılmasina ilişkin durum çalışması (Unpublished doctoral dissertation). Marmara University, İstanbul.

Özay, E., \& Hasenekoğlu, İ. (2007). Lise 3 biyoloji ders kitaplarındaki görsel sunumda gözlemlenen bazı sorunlar. Türk-Fen Eğitimi Dergisi, 4(1), 80-91.

Özdemir, A. Ş., \& Pusmaz, A. (2007). İlköğretim 2. kademe ders kitaplarının çağdaş eğitim ölçütlerine göre uygunluğunun incelenmesi. Yeditepe Üniversitesi Eğitim Fakültesi Dergisi, 2(2), 1-14.

Özerbaş, M. A. (2007). Yapılandırmacı öğrenme ortamının öğrencilerin akademik başarılarına ve kalıcılığına etkisi. Türk Ĕgitim Bilimleri Dergisi, 5(4), 609-635.

Özmen, H., (2004). Fen öğretiminde öğrenme teorileri ve teknoloji destekli yapılandırmacı (constructivist) öğrenme. The Turkish Online Journal of Educational Technology-TOJET, 3(1), 100-111.

Özsoy, H. (2007). İlköğretim 4-5. Sinıf Fen ve Teknoloji Ders Kitaplarının Öğrenci, Öğretmen ve Veli Görüşleri Kapsaminda Değerlendirilmesi (Unpublished master's thesis). Zonguldak Karaelmas University, Zonguldak.

Phoenix, D. A. (2000). Looking towards reform—the student focus. Journal of Biological Education, 34(4), 171. https://doi.org/10.1080/00219266.2000.9655713

Pop-Păcurar, L., \& Ciascai, L. (2010). Biology school textbooks and their role for students' success in learning sciences. Acta Didactica Napocensia, 3(1), 1-10. 
Robinson, T. J., Fischer, L., Wiley, D., \& Hilton III, J. (2014). The impact of open textbooks on secondary science learning outcomes. Educational Researcher, 43(7), 341-351. https://doi.org/10.3102/0013189X14550275

Roth, W. R., \& Roychoudhury, A. (1994). Physics students' epistemologies and views of knowing and learning, Journal of Research on Science Teaching, 31(1), 5-30. https://doi.org/10.1002/tea.3660310104

Saygın, Ö., Atılboz, N. G., \& Salman, S. (2006). Yapılandırmacı öğretim yaklaşımının biyoloji dersi konularını öğrenme başarısı üzerine etkisi: canlılı̆̆ın temel birimi-hücre. Gazi Üniversitesi Gazi Eğitim Fakültesi Dergisi, 26(1), 51-64.

Schaefer, G. (1979) Concept formation in biology: The concept "growth". European Journal of Science Education, 1(1), 87-101. https://doi.org/10.1080/0140528790010110

Semerci, CC. (2004). İlköğretim Türkçe ve matematik ders kitaplarını genel değerlendirme ölçeği. Ç.Ü. Sosyal Bilimler Dergisi, 28(1), 49-54.

SooHoo, S. (1993). Students as partners in research and restructuring schools. The Educational Forum, 57, 386-393. https://doi.org/10.1080/00131729309335445

Sosniak, L. A., \& Perlman, C. L. (1990). Secondary education by the book. Journal of Curriculum Studies, 22(5), 427-442. https://doi.org/10.1080/0022027900220502

Stenhouse, L. (1975). An introduction to curriculum research and development. London: Heinemann.

Suter, L. E., \& Frecthling, J. (2000). Guiding principles for mathematics and science education research methods: report of a workshop. Division of Research, Evaluation and Communication National Science Foundation. November 19-20, 1998. Arlington, Virginia.

Swanepoel, S. (2010). The assessment of the quality of science education textbooks: Conceptual framework and instruments for analysis (Unpublished Doctoral dissertation). University of South Africa.

Trowbridge, L. W., \& Bybee, R. W. (1996). Teaching secondary school science. Englewood Cliffs, NJ: Prentice Hall.

Tytler, R. (2002). Teaching for understanding in science: Student conceptions of research, and changing views of learning. Australian Science Teachers Journal, 48(3), 14-21.

Ünsal, Y., \& Güneş, B. (2004). Bir kitap inceleme çalışması örneği olarak meb lise sınıf fizik ders kitaplarının eleştirel olarak incelenmesi. Gazi Eğitim Fakültesi Dergisi, 3, 305-321.

Ünsal, Y., \& Güneş, B., (2003). Bir kitap inceleme çalışması örneği olarak meb ilköğretim 8.sınıf fen bilgisi ders kitabına fizik konuları yönünden eleştirel bir bakış. Kastamonu Eğitim Dergisi, 11(2), 387-394.

Valverde, G. A., Bianchi, L. J., Wolfe, R. G., Schmidt, W. H., \& Houang, R. T. (2002). According to the book: Using TIMSS to investigate the translation of policy into practice through the world of textbooks. Dordrecht, Netherlands: Kluwer. https://doi.org/10.1007/978-94-007-0844-0

Walberg, H. J. (1991). Improving school science in advanced and developing countries. Review of Educational Research, 61, 25-69. https://doi.org/10.3102/00346543061001025

Yaşar, Ş., \& Gültekin, M. (2009). Uzaktan eğitimde kullanılan ders kitaplarının yapısalcı öğrenmeyi gerçekleştirecek biçimde düzenlenmesi. Retrieved from http://aof20.anadolu.edu.tr/ bildiriler/sefik_yaşar.doc

Yıldırım, A. (2007). Seçilen bir ders kitabı değerlendirme ölçeğinin lise II fizik ders kitabına uygulanması (Unpublished master's thesis). Konya.

Yip, D. Y. (2001). Promoting the development of a conceptual change model of science instruction in prospective secondary biology teachers. International Journal of Science Education, 23(7), 755-770. https://doi.org/10.1080/09500690010016067

\section{Copyrights}

Copyright for this article is retained by the author(s), with first publication rights granted to the journal.

This is an open-access article distributed under the terms and conditions of the Creative Commons Attribution license (http://creativecommons.org/licenses/by/4.0/). 